DOI: $\mathrm{https://doi.org/10.31933/jimt.v2i3}$

Received: 21 November2020, Revised: 25 Desember 2020, Publish: 16 Februari 2021

JIMT
JURNAL ILMU MANAJEMEN
TERAPASTI

\title{
ANALISIS PERBANDINGAN KINERJA KEUANGAN PADA INDUSTRI SEKTOR PERKEBUNAN PERIODE 2014-2019 (STUDI PERBANDINGAN: PT LONDON SUMATERA INDONESIA TBK TERHADAP PT SALIM IVOMAS PRATAMA TBK)
}

\author{
Mulya Wicaksana ${ }^{1}$ \\ ${ }^{1)}$ Program Studi Magister Manajemen Universitas Mercu Buana, Jakarta, \\ mwicaksana@gmail.com
}

\begin{abstract}
Abstrak: Makalah ini mengkaji perkembangan kinerja keuangan PT Perusahaan Perkebunan London Sumatera Ind onesia Tbk (LSIP) selama 6 tahun yaitu tahun 2014 - 2019 dibandingkan dengan industri yang sama pada sektor perkebunan, yaitu PT Salim Ivomas Pratama Tbk (SIMP). Proses pengumpulan data menggunakan laporan keuangan akhir tahun pada tiap periodenya yang diambil dari Bursa Efek Indonesia (BEI). Penelitian menggunakan metode analisis deskriptif kualitatif, yaitu dengan teknik analisis rasio keuangan dari 6 tahun laporan keuangan dan metode analisis komparatif untuk mengetahui perkembangan serta penilaian kinerja keuangan perusahaan. Hasil penelitian menunjukkan bahwa kinerja keuangan PT Perusahaan Perkebunan London Sumatera Indonesia Tbk (LSIP) lebih baik dibandingkan dengan yaitu PT Salim Ivomas Pratama Tbk (SIMP) jika melihat seluruh analisa rasio.
\end{abstract}

Kata Kunci : Laporan Keuangan, Rasio Keuangan, Industri Sektor Perkebunan, LSIP, SIMP

\section{PENDAHULUAN}

Industri pada sektor perkebunan mempunyai kontribusi peran yang sangat penting, yaitu sebagai penyeimbang neraca perdagangan nasional. Adapun beberapa peran perkebunan adalah sebagai Peningkatan devisa negara dengan kualitas ekspor nya, Penyediaan bahan pangan dan bahan baku industry, Sumber utama pendapatan masyarakat pedesaan, Pengentasan kemiskinan, Penyediaan bahan bakar nabati, Pelestarian sumber daya alam dan Penurunan emisi gas rumah kaca.

Dengan makin berkembangnya sektor industri yang sama, dalam hal ini sektor perkebunan, membuat pihak pengamat perlu menganalisis lebih seksama kondisi laporan keuangan yang ada pada setiap perusahaan, agar pengambilan keputusan yang terkait dengan perusahaan tersebut tidak mengandung risiko kerugian.

Adapun data keuangan yang digunakan meliputi tiga laporan keuangan perusahaan, yaitu laporan keuangan laba-rugi, laporan arus kas, dan neraca. Laporan keuangan digunakan untuk memberikan informasi mengenai posisi keuangan dan kinerja perusahaan untuk mengambil keputusan. Selain itu dibutuhkan analisis rasio keuangan yang merupakan alat analisa yang digunakan untuk menilai kinerja keuangan berdasarkan data perbandingan keuangan pada suatu periode. 
Pihak pengamat dari analisis rasio keuangan dibagi menjadi dua pihak, yaitu pihak investor dan manajemen. Meski menggunakan analisis rasio keuangan yang sama, baik dalam segi prosedur mau pun jenis analisanya, kedua pihak memiliki tujuan penggunaan untuk kebutuhan yang berbeda.

Pihak investor memanfaatkan rasio keuangan untuk mengukur nilai investasi yang dilakukan sekaligus memprediksi untung atau rugi apabila berinvestasi di sebuah perusahaan. Dengan melakukan perbandingan rasio antara perusahaan atau bisnis, maka investor mampu menentukan investasi yang paling menguntungkan.

Di sisi manajemen, pemanfaatan rasio keuangan digunakan untuk memantau kinerja perusahaan sekaligus sebagai tolak ukur dalam evaluasi perkembangan bisnis. Contoh sederhananya adalah, sebuah perusahaan dapat mengetahui margin kotor yang rendah dalam analisa rasio keuangan, kemudian memikirkan cara untuk meningkatkannya.

\section{TINJAUAN LITERATUR}

Tinjauan literatur dalam sebuah penelitian berguna sebagai landasan teori yang dipergunakan dalam penelitian tersebut. Landasan teori tersebut dapat berupa hasil penelitian sebelumnya yang memiliki topik serupa ataupendapat para pakar yang ahli dalam subjek yang kita teliti.

\section{Sektor Perkebunan}

Sesuai informasi dari IDN Financial bahwa sector perkebunan mempunyai 21 perusahaan, dalam hal ini penulis mengambil dua perusahaan untuk dijadikan pembanding yaitu :

1. PT Perusahaan Perkebunan London Sumatera Indonesia Tbk (LSIP) adalah salah satu perusahaan yang bergerak di industri perkebunan kelapa sawit dan karet. Produk utamanya adalah minyak sawit mentah dan karet serta sejumlah kecil kakao, teh dan biji-bijian. Perusahaan ini merupakan anak perusahaan dari PT Salim Ivomas Pratama Tbk (SIMP). Perusahaan mulai beroperasi secara komersial pada tahun 1963

2. PT. Salim Ivomas Pratama Tbk (SIMP) adalah kelompok usaha agribisnis yang terdiversifikasi dan terintegrasi dengan operasi bisnis utama yang berkisar antara penelitian dan pengembangan, pengembangbiakan dan budidaya kelapa sawit, hingga penggilingan dan pemurnian minyak sawit mentah, dan pemasaran dan distribusi minyak goreng, margarin, shortening dan produk turunan lainnya. SIMP Group juga melakukan penanaman tanaman lain seperti karet, tebu, kakao dan teh. PT. Indofood Sukses Makmur Tbk (INDF) yang tergabung di Indonesia, dan Indofood Agri Resources Ltd., Singapura ("IndoAgri") adalah perusahaan induk dari kedua kelompok tersebut. First Pacific Company Limited, Hong Kong, adalah induk utama Grup

Laporan keuangan kedua perusahaan ini menggunakan auditor eksternal bernama Ersnt \& Young, yang merupakan perusahaan auditor big four.

\section{Laporan Keuangan}

Laporan keuangan perusahaan adalah laporan yang memberikan ikhtisar mengenai keadaan keuangan perusahaan, dimana neraca mencerminkan nilai aktiva, hutang, dan modal sendiri pada suatu periode tertentu; dan Laba Rugi mencerminkan hasil-hasil yang dicapai selama suatu periode tertentu dalam satu tahun. 
Tabel 1 - Laporan Keuangan PT Perusahaan Perkebunan London Sumatera Indonesia Tbk (LSIP)

\begin{tabular}{|c|c|c|c|c|c|c|}
\hline \multirow{2}{*}{ Laporan Keuangan } & \multicolumn{6}{|c|}{31 Desember } \\
\hline & 2014 & 2015 & 2016 & 2017 & 2018 & 2019 \\
\hline \multicolumn{7}{|l|}{ Neraca } \\
\hline \multicolumn{7}{|l|}{ Aktiva } \\
\hline Kas dan setara kas & $1,356.53$ & 737.11 & $1,140.61$ & $1,633.46$ & $1,663.46$ & $1,131.58$ \\
\hline Piutang & 84.59 & 112.20 & 202.75 & 175.45 & 152.03 & 468.62 \\
\hline * Piutang Usaha & 20.69 & 22.74 & 82.49 & 55.67 & 68.90 & 367.18 \\
\hline * Piutang Lain-lain & 63.90 & 89.46 & 120.25 & 119.78 & 83.13 & 101.44 \\
\hline Persediaan & 380.36 & 398.43 & 569.09 & 308.15 & 488.71 & 341.85 \\
\hline Aset Lancar & $1,863.51$ & $1,268.56$ & $1,919.66$ & $2,168.41$ & $2,444.03$ & $2,192.49$ \\
\hline Aset Tetap Bersih & $3,238.75$ & $3,427.97$ & $3,436.09$ & $3,233.98$ & $6,234.54$ & $6,311.10$ \\
\hline Aset Tidak Lancar & $6,849.57$ & $7,580.24$ & $7,539.43$ & $7,575.97$ & $7,593.27$ & $8,032.83$ \\
\hline Total Asset & $8,713.07$ & $8,848.79$ & $9,459.09$ & $9,744.38$ & $10,037.29$ & $10,225.32$ \\
\hline \multicolumn{7}{|l|}{ Pasiva } \\
\hline Hutang Lancar & 746.52 & 571.16 & 780.63 & 416.26 & 524.81 & 466.81 \\
\hline Hutang Jangka Panjang & 963.82 & 939.65 & $1,032.48$ & $1,205.96$ & $1,180.36$ & $1,260.02$ \\
\hline Total Hutang & $1,710.34$ & $1,510.81$ & $1,813.10$ & $1,622.22$ & $1,705.18$ & $1,726.82$ \\
\hline Ekuitas & $7,002.73$ & $7,337.98$ & $7,645.98$ & $8,122.17$ & $8,332.12$ & $8,498.50$ \\
\hline TU+TE & $8,713.07$ & $8,848.79$ & $9,459.09$ & $9,744.38$ & $10,037.29$ & $10,225.32$ \\
\hline \multicolumn{7}{|l|}{ Laba Rugi } \\
\hline Penjualan & $4,726.54$ & $4,189.62$ & $3,847.87$ & $4,738.02$ & $4,019.85$ & $3,699.44$ \\
\hline HPP & $(3,190.50)$ & $(3,073.77)$ & $(2,737.08)$ & $(3,395.18)$ & $(3,336.81)$ & $(3,137.88)$ \\
\hline EBIT & $1,536.04$ & $1,115.84$ & $1,110.79$ & $1,342.84$ & 683.03 & 561.56 \\
\hline Biaya Bunga & (314.09) & $(297.44)$ & (332.22) & (336.60) & (265.98) & $(208.82)$ \\
\hline EBT & $1,221.95$ & 818.41 & 778.56 & $1,006.24$ & 417.05 & 352.74 \\
\hline $\mathrm{PPH}$ & $(292.55)$ & (195.10) & (185.79) & $(242.81)$ & (87.63) & $(100.11)$ \\
\hline Laba Tahun Berjalan & 929.41 & 623.31 & 592.77 & 763.42 & 329.43 & 252.63 \\
\hline
\end{tabular}

PT Salim Ivomas Pratama Tbk (SIMP)

( Dalam Miliar Rupiah)

\begin{tabular}{|c|c|c|c|c|c|c|}
\hline \multicolumn{7}{|l|}{ Dalam Miliar Rupiah) } \\
\hline \multirow{2}{*}{ Laporan Keuangan } & \multicolumn{6}{|c|}{31 Desember } \\
\hline & 2014 & 2015 & 2016 & 2017 & 2018 & 2019 \\
\hline \multicolumn{7}{|l|}{ Neraca } \\
\hline \multicolumn{7}{|l|}{ Aktiva } \\
\hline Kas dan setara kas & $2,696.32$ & $1,461.30$ & $1,867.98$ & $2,260.61$ & $2,071.46$ & $1,716.80$ \\
\hline Piutang & 988.65 & $1,106.20$ & $1,119.17$ & $1,196.30$ & $1,392.59$ & $1,317.29$ \\
\hline * Piutang Usaha & 724.19 & 810.11 & $1,012.02$ & $1,073.86$ & $1,282.60$ & $1,209.23$ \\
\hline * Piutang Lain-lain & 264.46 & 296.09 & 107.15 & 122.44 & 109.99 & 108.06 \\
\hline Persediaan & $1,773.33$ & $1,936.73$ & $2,070.39$ & $2,102.76$ & $2,428.37$ & $2,253.71$ \\
\hline Aset Lancar & $6,010.49$ & $5,028.03$ & $5,729.30$ & $6,289.82$ & $6,988.91$ & $6,758.59$ \\
\hline Aset Tetap Bersih & $10,330.69$ & $10,810.81$ & $10,626.69$ & $10,261.43$ & $20,065.93$ & $20,342.29$ \\
\hline Aset Tidak Lancar & $24,985.56$ & $26,669.12$ & $26,808.30$ & $27,107.95$ & $27,677.60$ & $28,152.25$ \\
\hline Total Asset & $30,996.05$ & $31,697.14$ & $32,537.59$ & $33,397.77$ & $34,666.51$ & $34,910.84$ \\
\hline \multicolumn{7}{|l|}{ Pasiva } \\
\hline Hutang Lancar & $6,898.83$ & $5,373.08$ & $4,595.30$ & $6,187.99$ & $7,791.40$ & $8,806.63$ \\
\hline Hutang Jangka Panjang & $7,290.18$ & $9,092.66$ & $10,324.00$ & $9,029.00$ & $8,588.43$ & $8,322.89$ \\
\hline Total Hutang & $14,189.00$ & $14,465.74$ & $14,919.30$ & $15,216.99$ & $16,379.83$ & $17,129.52$ \\
\hline Ekuitas & $16,807.05$ & $17,231.40$ & $17,618.29$ & $18,180.78$ & $18,286.68$ & $17,781.32$ \\
\hline TU+TE & $30,996.05$ & $31,697.14$ & $32,537.59$ & $33,397.77$ & $34,666.51$ & $34,910.84$ \\
\hline \multicolumn{7}{|l|}{ Laba Rugi } \\
\hline Penjualan & $14,962.73$ & $13,835.44$ & $14,530.94$ & $15,826.65$ & $14,190.10$ & $13,650.39$ \\
\hline HPP & $(10,865.67)$ & $(10,734.95)$ & $(11,081.00)$ & $(12,402.62)$ & $(11,732.28)$ & $(11,564.71)$ \\
\hline EBIT & $4,097.06$ & $3,100.49$ & $3,449.94$ & $3,424.03$ & $2,457.82$ & $2,085.68$ \\
\hline Biaya Bunga & $(2,450.42)$ & $(2,422.66)$ & $(2,055.32)$ & $(2,230.16)$ & $(2,251,10)$ & $(2,282.83)$ \\
\hline EBT & $1,646.64$ & 677.83 & $1,394.63$ & $1,193.87$ & 206.72 & $(197.15)$ \\
\hline $\mathrm{PPH}$ & $(537.28)$ & (312.96) & (784.83) & $(498.44)$ & (384.79) & $(445.05)$ \\
\hline Laba Tahun Berjalan & $1,109.36$ & 364.88 & 609.79 & 695.43 & $(178.07)$ & $(642.20)$ \\
\hline
\end{tabular}

Tabel 2 - Laporan Neraca PT Salim Ivomas Pratama Tbk (SIMP)

\section{Rasio Keuangan}

Analisi Laporan Keuangan adalah konsep analisis keuangan yang mempunyai hubungan-hubungan kuantitatif untuk mendiagnosa kekuatan dan kelemahan dalam kinerja suatu perusahaan.

Manfaat Analisis Rasio Keuangan adalah untuk membantu penganalisis untuk mengetahui keadaan dan perkembangan keuangan perusahaan yang bersangkutan. 
Untuk mengambil manfaat rasio keuangan diperlukan standar untuk perbandingan. Salah satu pendekatan adalah membandingkan rasio perusahaan dengan pola industri atau lini usaha dimana perusahaan secara dominan beroperasi.

Berdasarkan sumbernya, rasio keuangan dibagi menjadi tiga yaitu :

1. Rasio-rasio Neraca

Adalah rasio-rasio yang disusun dari data yang berasal dari neraca. Misalnya : current ratio, current assets to total assets ratio, current liabilities to total assets ratio, dan lainnya

2. Rasio-rasio Statemen Laba Rugi

Rasio-rasio yang disusun berdasarkan income statements, missal gross profit margin, net operating margin, operating ratio, dan lainnya

3. Rasio-rasio Antar Statemen Keuangan

Rasio keuangan yang disusun berdasarkan neraca dan data lainnya yang berasal dari income statement, misalnya assets turnover, inventory turnover, receivab;e turnover, dan sebagainya.

\section{Jenis-Jenis Rasio Keuangan}

Menurut Budi Raharjo dalam buku Keuangan Dan Akuntansi (2007) mengelompokkan rasio keuangan perusahaan menjadi empat rasio keuangan yang digunakan dalam menganalisis, yaitu:

1. Rasio Likuiditas atau Liquidity Ratio adalah rasio yang mengukur kemampuan likuiditas jangka pendek suatu perusahaan dengan melihat aktiva lancar perusahaan relative terhadap utang lancarnya;

2. Rasio Solvabilitas atau Solvability Ratio adalah rasio aktivitas menunjukkan tingkat efektivitas penggunaan aktiva atau kekayaan perusahaan;

3. Rasio Aktivitas atau Activity Ratio rasio ini melihat pada beberapa asset kemudian menentukan berapa tingkat aktivitas aktiva-aktiva tersebut pada tingkat kegiatan tertentu; dan

4. Rasio Profitabilitas atau Profitability Ratio merupakan rasio yang menunjukkan tingkat imbalan atau perolehan (keuntungan) dibanding penjualan atau aktiva.

\section{Rasio Likuiditas}

Rasio likuiditas menunjukan kemampuan perusahaan memenuhi kewajiban finansial jangka pendeknya. Rasio yang sering digunakan untuk menghitung ini yaitu.

- Current Ratio, rasio ini menunjukan perbandingan aset lancar dengan kewajiban lancar.

- Quick Ratio, menunjukkan perbandingan antara (kas + sekuritas jangka pendek + piutang) dengan kewajiban lancar. Dengan kata lain merupakan jumlah perimbangan antara aktiva lancar dikurangi persediaan dengan hutang lancar.

\section{Rasio Solvabilitas}

Menunjukkan kemampuan perusahaan untuk memenuhi semua kewajibannya baik jangka panjang maupun jangka pendek jika perusahaan di likuidasi.. Terdapat 2 rasio yang digunakan untuk menghitungnya.

- Total Debt to Total Assets Ratio: Rasio ini dikenal dengan debt ratio yaitu mengukur besarnya dana yang berasal dari utang. 
- Debt to Equity Ratio: Rasio ini digunakan untuk mengukur utang yang dimiliki dengan modal sendiri. Sebaiknya utang perusahaan tidak melebihi modal perusahaan sendiri.

\section{Rasio Aktivitas}

Cara menghitung rasio aktivitas adalah dengan melihat beberapa aset, kemudian Anda menentukan berapa tingkat aktivitas pada aktiva-aktiva pada kegiatan tertentu. Setelah itu, Anda akan mengetahui aktiva mana yang produktif dan aktiva mana yang kurang produktif.

- Rasio Perputaran Piutang: Rasio ini mengukur efektivitas pengelolaan piutang. Melalui rasio ini Anda dapat melihat pengelolaan piutang dan kebijakan kredit nya.

- Rasio Perputaran Persediaan: Rasio ini menunjukan likuiditas perusahaan dalam pengelolaan persediaan nya. Semakin tinggi perputaran nya maka semakin baik. Jika rendah berarti efektivitas pengendalian persediaan kurang baik.

- Rasio Perputaran Aktiva Tetap: Rasio ini mengukur sejauh mana kemampuan perusahaan menghasilkan penjualan dengan aktiva tetap yang dimilikinya. Semakin besar perputaran rasio nya, maka semakin baik untuk perusahaan.

- Rasio Perputaran Total Aktiva: Rasio ini digunakan untuk menghitung efektivitas penggunaan total aktiva.

\section{Rasio Profitabilitas}

Rasio profitabilitas menunjukan kemampuan perusahaan menghasilkan keuntungan (laba). Dengan menggunakan rasio ini Andad apat mengetahui kelangsungan hidup perusahaan (going concern). Terdapat lima ukuran yang dapat digunakan untuk mengukur rasio profitabilitas.

- Gross Profit Margin, merupakan perbandingan laba kotor dan penjualan pada periode yang sama.

- Operating Profit Margin, profit margin menggambarkan laba bersih sebelum bunga dan pajak yang didapat dari penjualan perusahaan. Rasio ini dapat dilihat pada laporan laba rugi pada bagian analisis common size.

- Net Profit Margin, rasio ini mengukur jumlah rupiah laba bersih yang dihasilkan oleh setiap satu penjualan rupiah.

- Return On Assets (ROA), menunjukan kemampuan perusahaan menghasilkan after tax operating profit dari total aset yang dimiliki perusahaan. Laba yang dihitung adalah laba sebelum bunga dan pajak atau EBIT (Earning Before Interest and Tax).

- Return On Investment (ROI), analisis ini menunjukkan kemampuan perusahaan untuk menghasilkan keuntungan yang akan digunakan untuk menutup investasi yang dikeluarkan. Laba yang digunakan untuk menghitung rasio ini adalah laba setelah pajak / Earning After tax (EAT).

\section{METODE PENELITIAN}

Metode penelitian atau metode ilmiah adalah prosedur atau langkah-langkah dalam mendapatkan pengetahuan ilmiah atau ilmu. Jadi metode penelitian adalah cara sistematis untuk menyusun ilmu pengetahuan. Sedangkan teknik penelitian adalah cara untuk melaksanakan metode penelitian. Metode penelitian biasanya mengacu pada bentuk-bentuk penelitian.

Menurut Suryana (2010), empat macam metode penelitian :

(1) Metode eksperimen (ujicoba), adalah penelitian untuk menguji apakah variabel-variabel eksperimen efektif atau tidak. Untuk menguji efektif tidaknya harus digunakan variabel 
kontrol. Penelitian eksperimenadalah untuk menguji hipotesis yang dirumuskan secara ketat. Penelitian eksperimen biasanya dilakukan untuk bidang yang berssifat eksak. Sedangkan untuk bidang sosaial bisanya digunakan metode survey eksplanatory, metode deskriptif, dan historis.

(2) Metode Verifikasi (Pengujian), yaitu untuk menguji seberapa jauh tujuan yang sudaah digariskan itu tercapai atau sesuaai atau cocok ddengan harapan atau teori yang sudah baku. Tujuan daari penelitian verifikasi adalah untuk menguji teori-teori yang sudah ada guna menyusun teori baru dan menciptakan pengetahuan-pengetahuan baru. Lebih mutakhirnya, metode verifikasi berkembang menjadi grounded research, yaitu metode yang menyajikan suatu pendekatan baru, dengan data sebagai sumber teori (teori berdasarkan data).

(3) Metode Deskriptif (mendeskripsikan), yaitu metode yang digunakan untuk mencari unsurunsur, ciri-ciri, sifat-sifat suatu fenomena. Metode ini dimulai dengan mengumpulkan data, menganalisis data dan menginterprestasikannya. Metode deskriptif dalam pelaksanaannya dilakukan melalui: teknik survey, studi kasus (bedakan dengan suatu kasus), studi komparatif, studi tentang waktu dan gerak, analisis tingkah laku, dan analisis dokumenter.

(4) Metode Historis (merekonstruksi), yaitu suatu metode penelitian yang meneliti sesuatu yang terjadi di masa lampau. Dalam penerapannya, metode ini dapat dilakkan dengan suatu bentuk studi yang bersifat komparatif-historis, yuridis, dan bibliografik. Penelitian historis bertujuan untuk menemukan generaalisasi dan membuat rekontruksi masa lampau, dengan cara mengumpulkan, mengevaluasi, memverifikasi serta mensintesiskan bukti-bukti untuk enegakkan fakta-fakta dan bukti-bukti guna memperoleh kesimpulan yang kuat.

Dalam penulisan ini, metode penelitian menggunakan metode Deskriptif dengan studi komparatif antar dua perusahaan sektor perkebunan :

1. Pengumpulan data:

a. Laporan keuangan PT Perusahaan Perkebunan London Sumatera Indonesia Tbk (LSIP) dan PT. Salim Ivomas Pratama Tbk (SIMP) berasal dari situs www.IDNFinancials.com

b. Rumus rasio keuangan berasal dari catatan pengajar bidang studi Corporate Finance Management

c. Beberapa data kualitatif mengenai penggunaan rasio keuangan di beberapa situs web

2. Menganalisis Data

a. Membuat perhitungan analisis rasio keuangan per masingn-masing perusahaan, dengan menghitung :

i. Rasio Likuiditas atau Liquidity Ratio

ii. Rasio Solvabilitas atau Solvability

iii. Rasio Aktivitas atau Activity Ratio

b. Membuat grafik perbandingan atas masing-masing rasio keuangan

3. Menginterpretasikan

Membuat pandangan teoritis terhadap studi perbandingan atas laporan keuangan PT Perusahaan Perkebunan Lond on Sumatera Indonesia Tbk (LSIP) dan PT. Salim Ivomas Pratama Tbk (SIMP) 


\section{HASIL DAN PEMBAHASAN}

Tabel 3 - Analisa Rasio LSIP dan SIMP

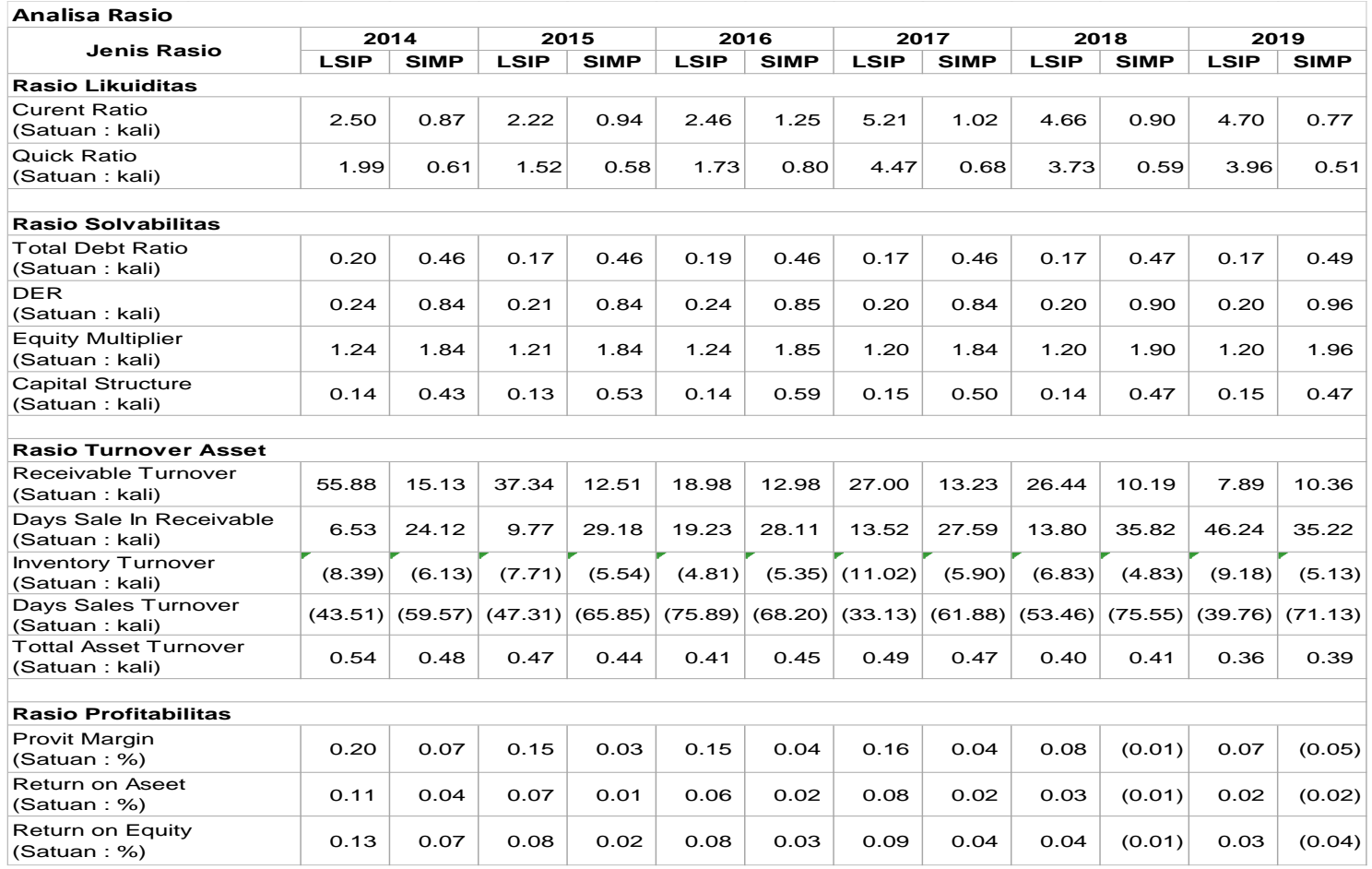

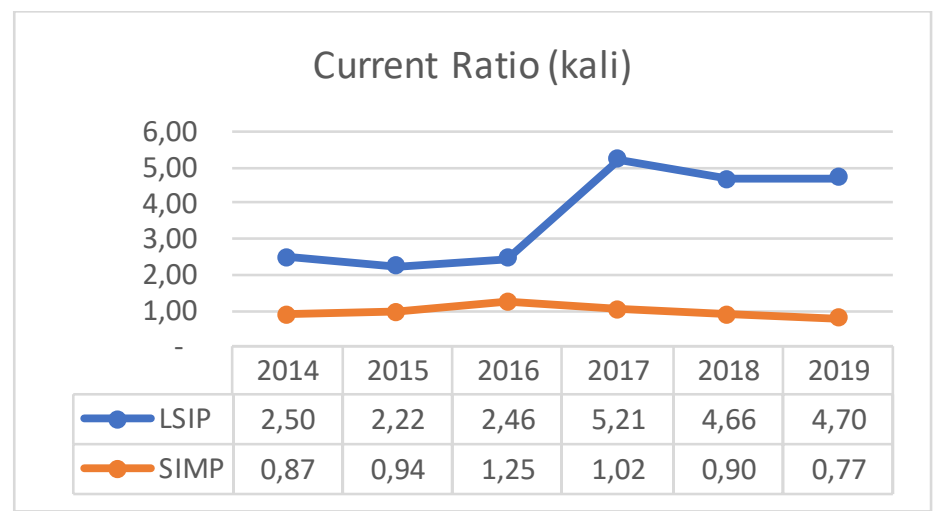

\section{Grafik 1 - Perbandingan Current Ratio LSIP dan SIMP}

Current Ratio menunjukkan kemampuan untuk membayar hutang yang segera harus dipenuhi dengan aktiva lancar. Semakin tinggi rasio lancarnya, maka semakin likuid perusahaannya. Berdasarkan grafik di atas, terlihat LSIP di 3 tahun pertama (2014-2016) terlihat agak stabil, namun di tahun 2017 current ratio melonjak tinggi sebesar 2.75 dari tahun 2016 menunjukkan tingkat likuid yang semakin baik. Akan tetapi tahun 2018 menurun sedikit ke kisaran 4.66. Dan setelah itu di tahun 2019, cukup stabil jika dibandigkan tahun 2018. Jika dibandingkan dengan SIMP, LSIP masih berada di posisi atas di tiap tahun nya. Artinya dalam 6 tahun, LISP memiliki likuiditas yang baik dibandingkan dengan SIMP. 


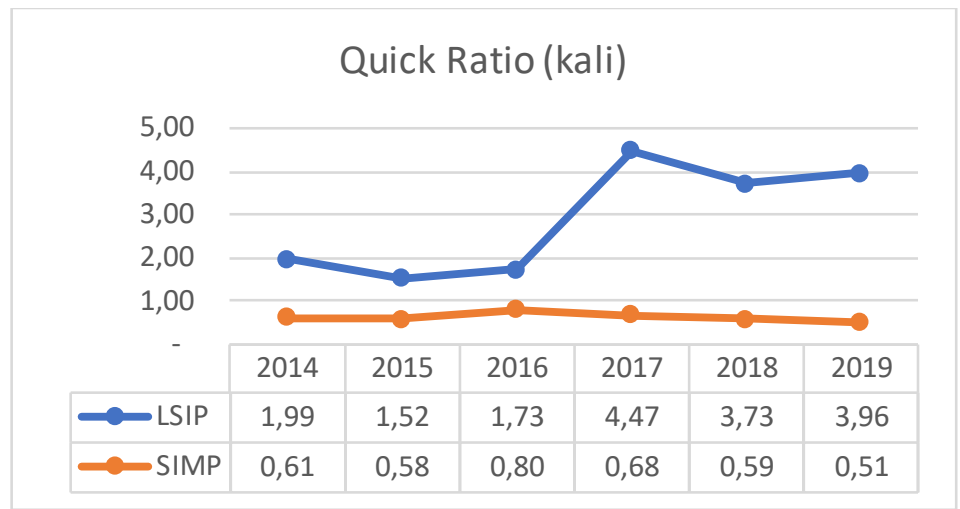

Grafik 2 - Perbandingan Quick Ratio LSIP dan SIMP

Quick Ratio menunjukkan kemampuan untuk membayar hutang yang segera dipenuhi, dengan aktiva/asset yang lebih likuid.

Quick Ratio yang dapat diterima umumnya adalah 1 kali (Quick Ratio $>1$ ). Perusahaan dengan rasio lancar $<1$ kali menandakan perusahaan yang bersangkutan tidak dapat membayar kewajiban lancar nya dalam waktu yang singkat.

Berdasarkan grafik di atas, terlihat LSIP di 3 tahun pertama (2014-2016) terlihat cukup stabil dengan berada di atas 1.50 kali, namun di tahun 2017 quick ratio melonjak tinggi sebesar 2.74 dari tahun 2016 menunjukkan LSIP mempunyai kemampuan untuk membayar hutang yang segera dipenuhi dengan asset yang lebih likuid. Akan tetapi tahun 2018 menurun sedikit ke kisaran 3.73. Dan setelah itu di tahun 2019, cukup stabil jika dibandingkan tahun 2018. Quick Ratio LSIP termasuk yang dapat diterima karena selama 6 tahun quick ratio nya $>1$ Jika dibandingkan dengan SIMP, LSIP dinilai baik karena masih berada di posisi atas di tiap tahun nya. Sed angkan quick ratio SIMP berada di bawah 1, menandakan SIMP tidak dapat membayar kewajiban lancarnya dalam waktu singkat.

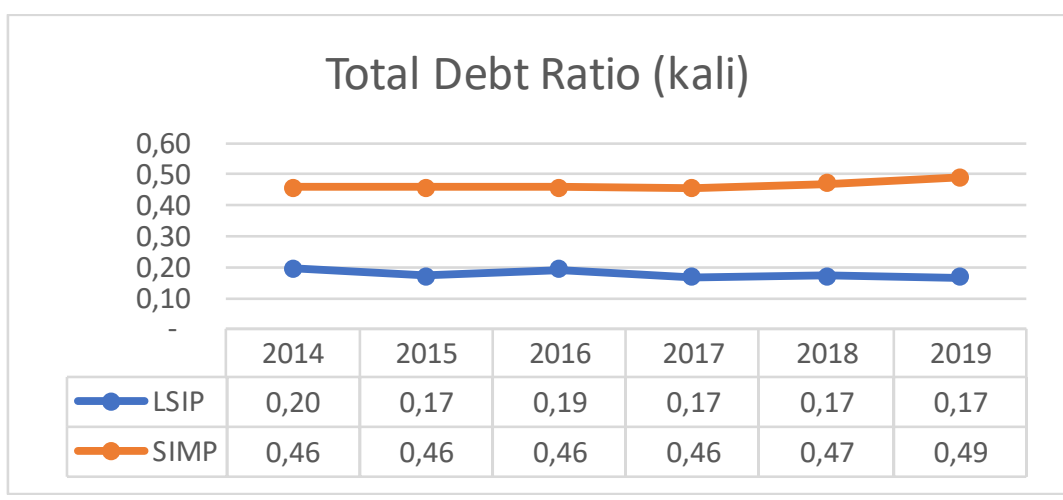

Grafik 3 - Perbandingan Total Debt Ratio LSIP dan SIMP

Total debt ratio dapat menunjukkan seberapa besar aktiva yang dimiliki oleh perusahaan dibiayai oleh hutang. Semakin besar nilai rasio ini artinya aktiva yang dimiliki oleh perusahaan dibiayai atau dibeli dengan menggunakan hutang. Sehingga semakin besar nilai rasio ini maka semakin besar pula risiko bagi para kreditur atau pihak yang memberikan pinjaman kepada perusahaan.

Berdasarkan grafik di atas, dari tahun 2014 sampai 2019, LSIP mempunyai total debt ratio dibawah 1 kali. Dari tahun 2017 sampai 2019 debt ratio LSIP berada di posisi yang sama, $17 \%$ asset yang dimiliki LSIP dibiayai oleh hutang, sedangkan $83 \%$ asset lainnya dibiayai oleh modal. 
Jika dibandingkan dengan SIMP, dari tahun 2014 sampai 2019, LSIP mempunyai rasio yang lebih kecil dengan tingkat perbedaannya rata-rata 0.29. Artinya LSIP mempunyai risiko yang lebih kecil dari SIMP bagi para pihak yang memberikan pinjaman.

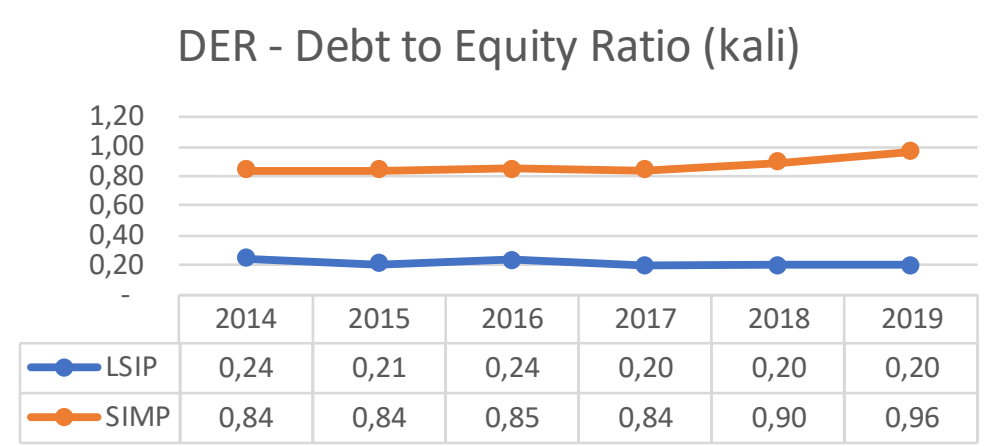

\section{Grafik 4 - Perbandingan Debt to Equity Ratio LSIP dan SIMP}

Total debt to equity ratio merupakan satu ukuran perbandingan antara total hutang perusahaan dibandingkan dengan modal perusahaan atau menunjukkan seberapa besar tingkat hutang perusahaan terhadap modalnya. Debt to equity ratio yang optimal adalah sekitar 1 kali, dimana jumlah hutang $=$ jumlah modal.

Berdasarkan grafik di atas, dari tahun 2014 sampai 2019, LSIP mempunyai debt to equity ratio dibawah 1 kali. Dari tahun 2017 sampai 2019 debt ratio LSIP berada di posisi yang sama, yaitu $20 \%$ dari setiap rupiah modal sendiri menjadi jaminan hutang.

Jika dibandingkan dengan SIMP, dari tahun 2014 sampai 2019, LSIP mempunyai debt to equity ratio yang lebih kecil dengan tingkat perbedaannya rata-rata 0.65 . Artinya LSIP mempunyai risiko yang lebih kecil dari SIMP.

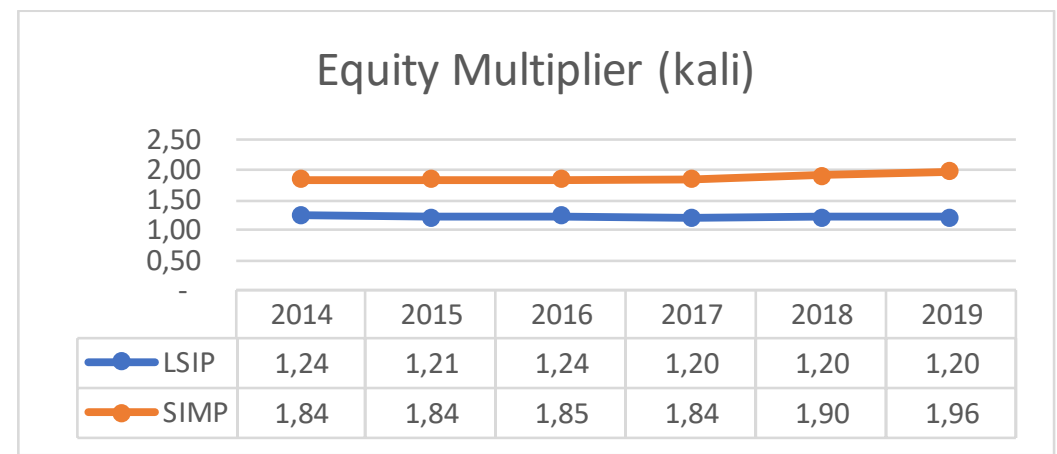

Grafik 5 - Perbandingan Equity Multiplier LSIP dan SIMP

Equity multiplier (EM) ratio merupakan rasio yang menunjukkan kemampuan perusahaan dalam mendayagunakan ekuitas pemegang saham. Rasio ini juga diartikan sebagai berapa porsi dari aktiva perusahaan yang dibiayai oleh pemengang saham. Semakin kecil rasio ini semakin besar porsi pemegang saham, sehingga kinerjanya semakin baik, karena persentase untuk pembayaran bunga semakin kecil.

Berdasarkan grafik di atas, LSIP mempunyai rasio yang relative sama yaitu berada di sekitar 1.2 kali. Dan tahun 2017 sampai 2019 cukup stabil berada di 1,20. Jika dibandingkan dengan SIMP, dari tahun 2014 sampai 2019, LSIP mempunyai Equity multiplier (EM) ratio yang lebih kecil dengan tingkat perbedaan di tahun 2019 sebesar 0.76. Artinya LSIP mempunyai kinerja yang lebih baik dibandingkan SIMP karena porsi dari aktiva LSIP yang 
dibiayai oleh pemegang saham lebih besar dari SIMP. Dan LSIP mempunyai porsi untuk pembayaran bunga semakin kecil dibandingkan SIMP.

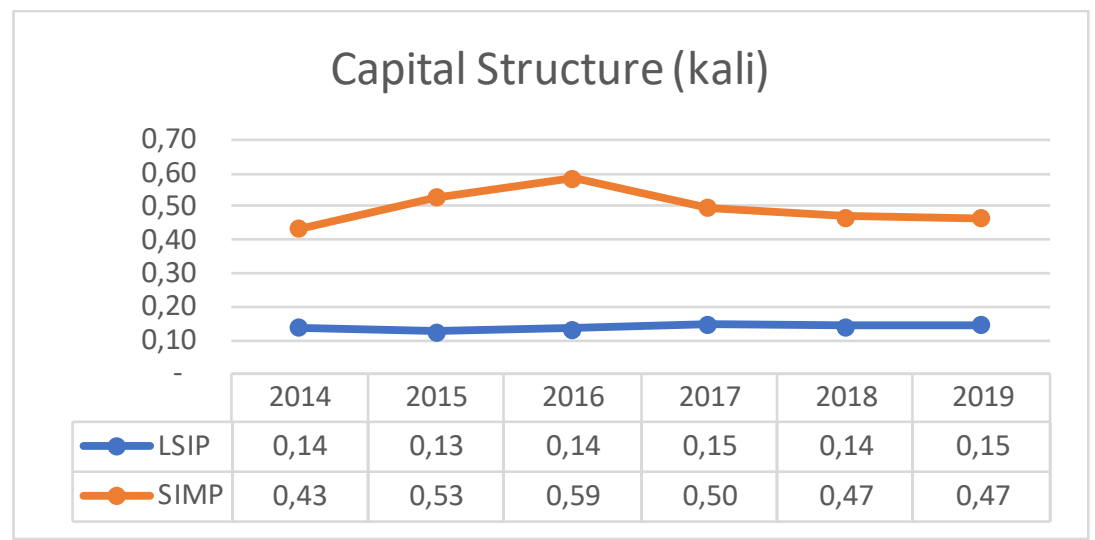

Grafik 6 - Perbandingan Capital Structure LSIP dan SIMP

Capital Structure adalah rasio yang menilai atau mengukur perbandingan antara hutang jangka panjang dengan modalnya. Tujuan rasio ini adalah untuk mengukur seberapa banyak bagian dari setiap modal yang dijadikan sebagai penjamin hutang jangka panjang. Berdasarkan grafik di atas, LSIP mempunyai rasio yang relative stabil, yaitu rata-rata daritahun 2014 sampai 2019 adalah 0.14. Sedangkan hasil rata-rata SIMP dengan periode tahun yang sama, berada di 0.50. Sehingga dapat disimpulkan bahwa nilai capital structure LSIP berada pada posisi lebih rendah di bandingkan dengan SIMP. Dapat disimpulkan bahwa LSIP lebih baik di bandingkan SIMP.

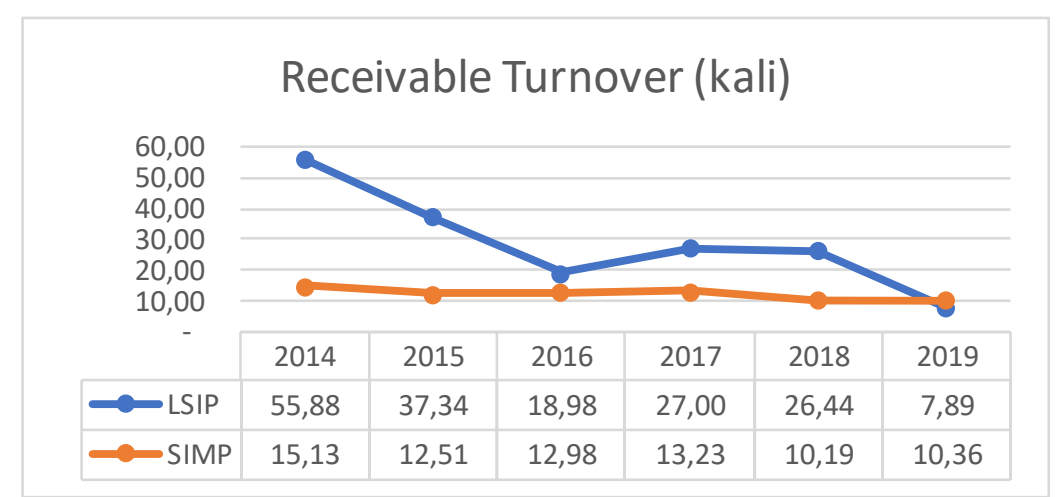

\section{Grafik 7 - Perbandingan Receivable Turn Over LSIP dan SIMP}

Receivable TurnOver atau rasio perputaran piutang adalah rasio yang mengukur kemampuan dan efisiensi perusahaan dalam menagih piutang, semakin tinggi rasio ini akan semakin baik dan menguntungkan. Berdasarkan grafik diatas, dapat dilihat LSIP di tahun 2014 mempunyai rasio 55.88 kali. Dalam 6 tahun periode, tahun 2014 itulah rasio yang terbagus. Di tahun 2015 mulai turun sampai 2016 dengan rasio 18.98 kali. Tahun 2017 kembali meningkat ke 27.00. Di tahun 2019, rasio menurun ke 7.89, terdapat penurunan yang cukup signifikan dibandingkan tahun 2018 yang berada di 26.44. Jika dibandingkan dengan SIMP, dalam tahun 2014 sampai 2018, LSIP berada pada posisi lebih tinggi. Namun pada tahun 2019, SIMP menjadi lebih tinggi sebesar 2.47 dari LSIP. Artinya di tahun 2019 SIMP mempunyai kemampuan dalam menagih piutang lebih baik daripada LSIP 


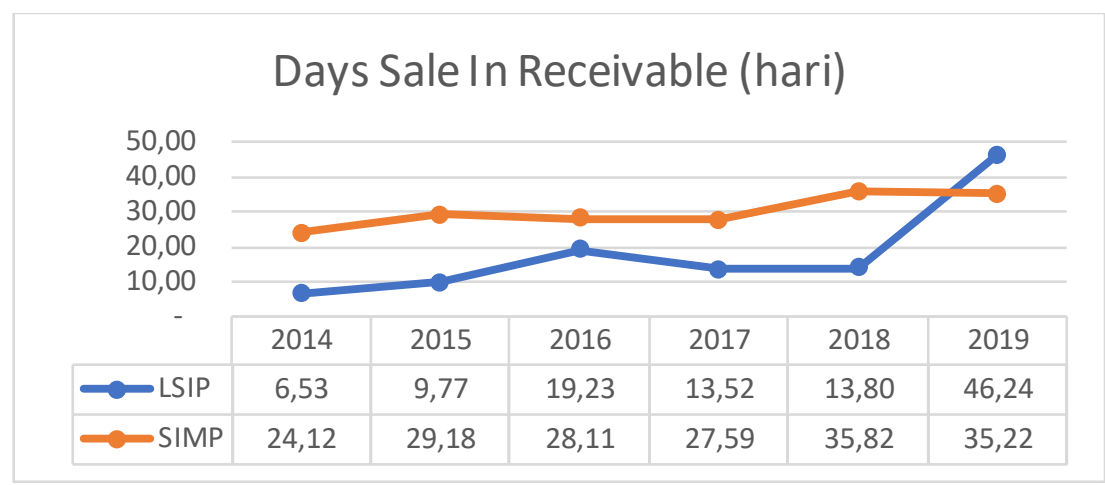

\section{Grafik 8 - Perbandingan Days Sale in Receivable LSIP dan SIMP}

Day's sale in receivable dapat menunjukkan berapa lama rata-rata waktu yang dibutuhkan perusahaan untuk menagih setiap piutang yang tertagih. Semakin kecil nilai day's sale in receivable semakin cepat piutang dilunasi. Berdasarkan grafik diatas dapat dilihat bahwa day's sale in receivable LSIP perbandingan dengan SIMP bervariasi dari tahun ke tahun. Oleh karena itu untuk hasil yang lebih akurat mengambil nilai rata-rata day's sale in receivable selama enam tahun. Hasil rata-rata nilai day's sale in receivable LSIP sebesar 18 hari sedangkan SIMP sebesar 30 hari. Sehingga dapat disimpulkan bahwa nilai day's sale in receivable LSIP lebih bagus dari pada SIMP dan LSIP dapat semakin cepat piutangnya dilunasi.

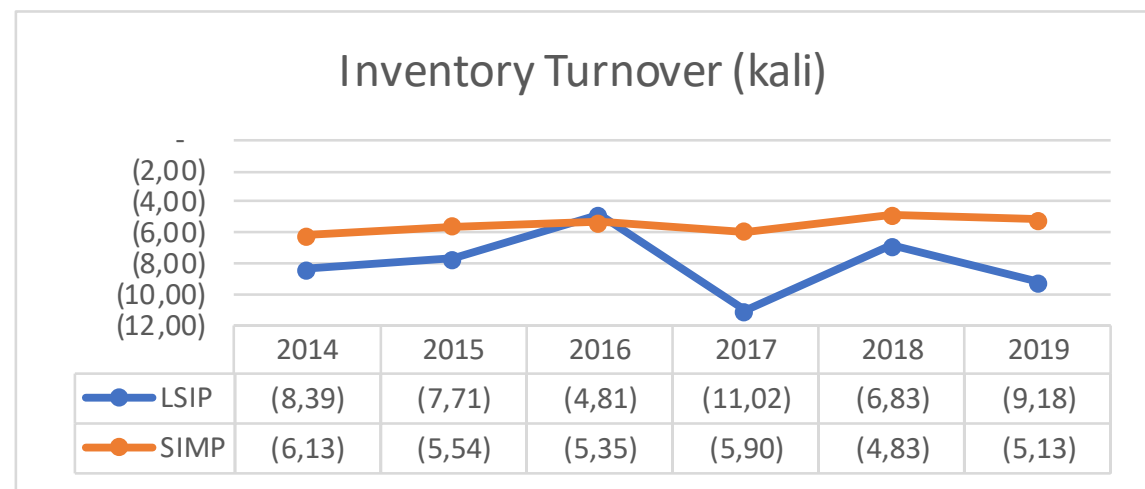

Grafik 9 - Perbandingan Inventory Turnover LSIP dan SIMP

Inventory turnover dapat menunjukkan berapa kali persediaan dapat berputar dalam satu tahun atau dapat juga dikatakan rasio ini menunjukkan tingkat efisiensi dan efektifitas dari persediaan. Semakin tinggi nilai inventory turnover menunjukkan perusahaan menjual persediaan secara maksimal. Berdasarkan grafik diatas dapat dilihat bahwa perbandingan antara LSIP dan SIMP bervariasi dalam 6 tahun (periode 2014-2019), oleh karena itu untuk hasil yang akurat dilakukan rata-rata terhadap dua perusahaan ini. LSIP mempunyai rata-rata (7.99) dan SIMP mempunyai rata-rata (5.48). Rata-rata Inventory turnover LSIP lebih kecil dibandingkan dengan SIMP. Artinya dapat disimpulkan LSIP lebih baik dalam penjualan persediaannya dibandingkan dengan SIMP. 


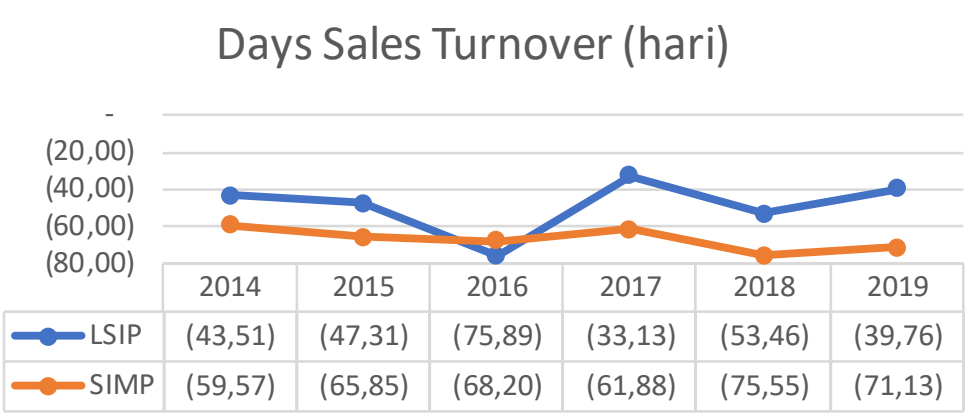

Grafik 10 - Perbandingan Days Sales Turnover LSIP dan SIMP

Day's sales turnover dapat menunjukkan berapa lama rata-rata waktu yang dibutuhkan perusahaan untuk tingkat efisiensi dan efektifitas dari persediaan Semakin kecil nilai Day's sales turnover menunjukkan perusahaan menjual persediaan secara maksimal. Berdasarkan grafik diatas dapat dilihat bahwa day's sale in receivable LSIP perbandingan dengan SIMP bervariasi dari tahun ke tahun. Oleh karena itu untuk hasil yang lebih akurat mengambil nilai rata-rata Day's sales turnover selama enam tahun. Hasil rata-rata nilai Day's sales turnover LSIP sebesar 48.84 hari sedangkan SIMP sebesar 67.03 hari. Sehingga dapat disimpulkan bahwa nilai Day's sales turnover LSIP lebih bagus dari pada SIMP, dan LSIP lebih efesiensi daripada SIMP alam penjualan persediaannya.

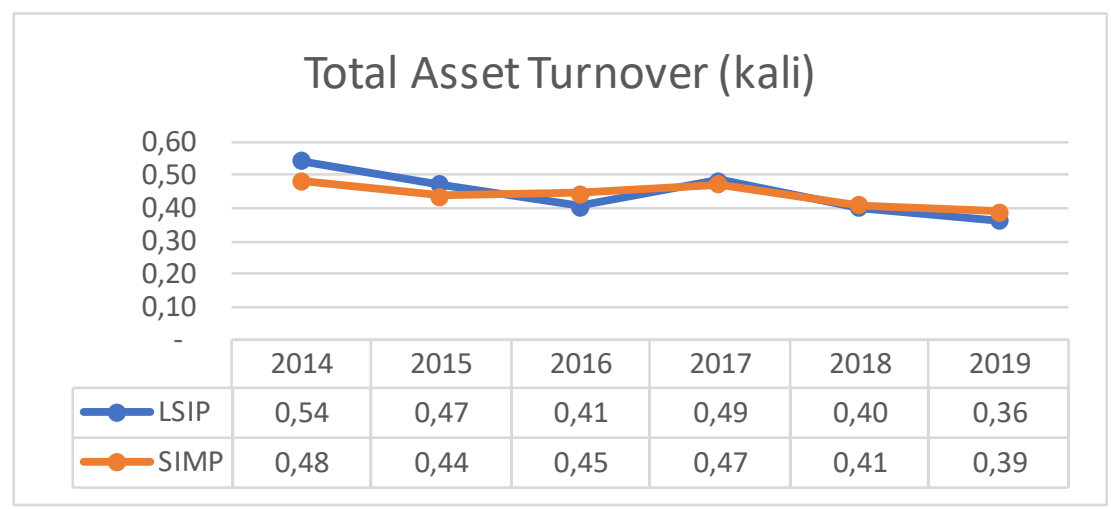

Grafik 11 - Perbandingan Total Asset Turnover LSIP dan SIMP

Total Asset Turnover Ratio digunakan seberapa efisiennya sebuah perusahaan menggunakan asetnya untuk menghasilkan penjualan. Ini artinya semakin tinggi rasio nya semakin efisien perusahaan tersebut menggunakan asetnya untuk menghasilkan penjualan. Berdasarkan grafik di atas, dari tahun 2014 sampai 2019, LSIP mempunyai penurunan total asset turnover ratio. Di tahun 2014, rasio perputaran asetnya adalah 0.54 . Namun di tahun 2019, rasio perputarannya turun menjadi 0.36. Jika dibandingkan dengan SIMP, jika dari tahun 2014 sampai 2019 maka LSIP mempunyai rasio rata-rata perputaran sebesar 0.45 dan SIMP mempunyai rasio rata-rata perputaran sebesar 0.44. Artinya LSIP lebih besar dari SIMP, jadi LSIP lebih efisien dalam penggunaan asetnya untuk menghasilkan revenue. 


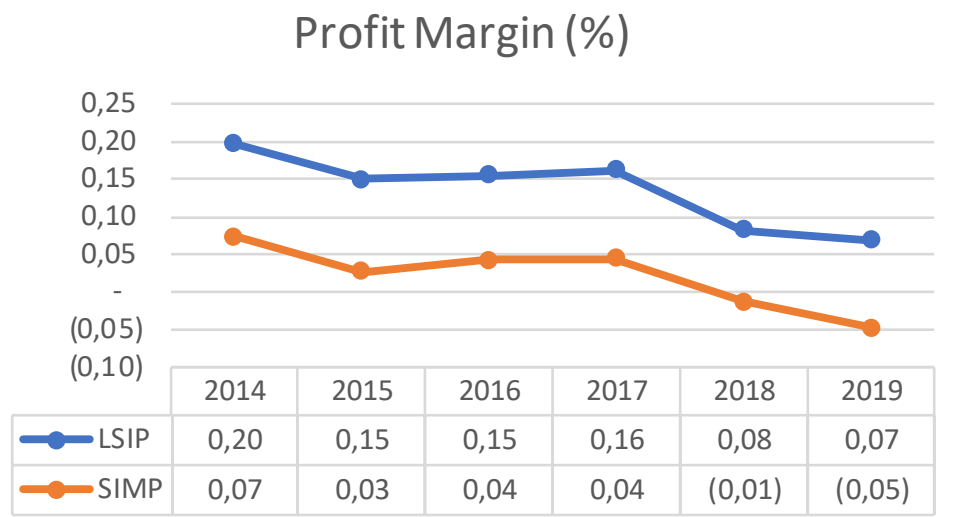

Grafik 12 - Perbandingan Profit Margin LSIP dan SIMP

Profit Margin adalah rasio yang mengukur sejauh mana kemampuan perusahaan dalam menghasilkan laba, baik itu laba kotor terhadap penjualannya dalam periode tertentu. Berdasarkan dari grafik di atas, terlihat bahwa profit margin LSIP di tahun 2014 sebesar $0.20 \%$, kemudian ditahun berikutnya menjadi semakin turun. Di tahun 2019 mencapai 0.07\%. Artinya kemampuan LSIP dalam menghasilkan laba menurun tiap tahunnya. Pergerakan SIMP pun mirip dengan pergerakan LSIP dimana pada tahun 2014 profit marginnya sebesar $0,07 \%$ namun di tahun 2017 mencapai minus $0.05 \%$. Namun jika LSIP dibandingkan dengan SIMP, profit margin LSIP lebih baik dari SIMP, artinya LSIP lebih mampu dalam menghasilkan laba.

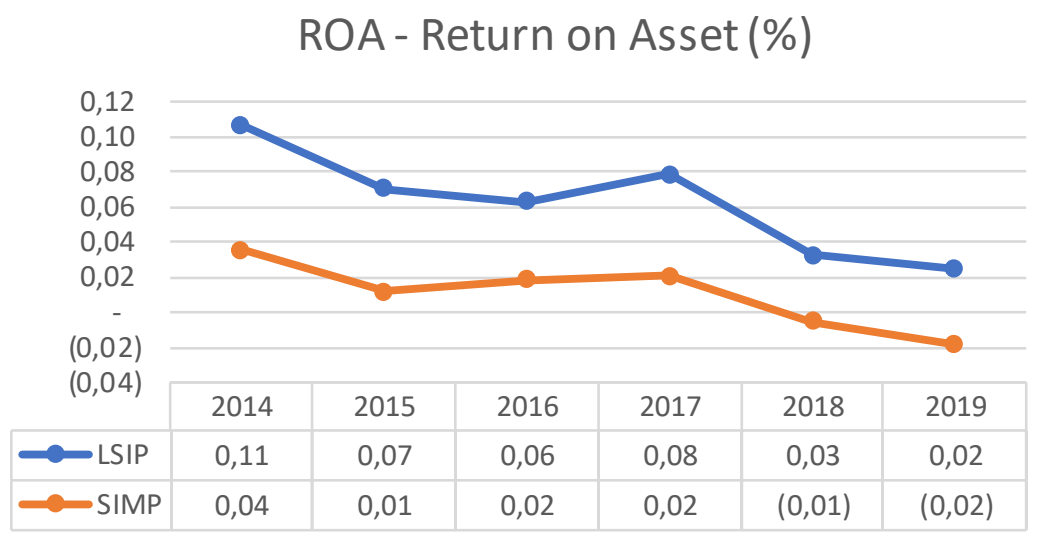

Grafik 13 - Perbandingan Return on Asset LSIP dan SIMP

Return on asset (ROA) dapat menunjukkan seberapa besar keuntungan yang dapat diperoleh atau dihasilkan perusahaan dari asset yang dimiliki perusahaan. Semakin tinggi nilai return on asset maka semakin tinggi pula laba yang dihasilkan perusahaan dari asset yang dimilikinya. Berdasarkan grafik di atas, terlihat bahwa return on asset LSIP di tahun 2014 sebesar $0.11 \%$, kemudian di tahun berikutnya menjadi semakin turun. Naik sedikit di tahun 2017 sebesar 0.02 dibandingkan tahun 2016. Di tahun 2019 mencapai 0.02\%. Artinya keuntungan LSIP dari asset yang dimiliki dalam 6 tahun mengalami penurunan. Sedangkan pergerakan SIMP pada tahun 2014 return on asset nya sebesar 0,04\% dan menurun terus sampai tahun 2019 dengan angka 0.02\%. Namun jika LSIP diband ingkan dengan SIMP, return on asset LSIP lebih baik dari SIMP, artinya LSIP mempunyai keuntungan yang lebih tinggi dibanding SIMP. 


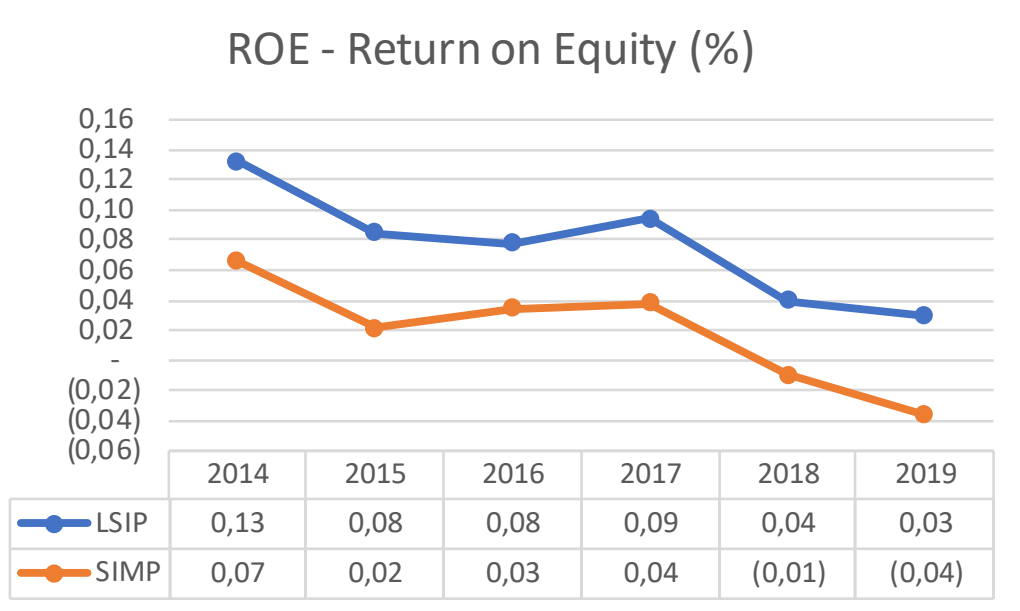

Grafik 14 - Perbandingan Return on Equity LSIP dan SIMP

Return on equity dapat menunjukkan seberapa besar keuntungan yang dapat diperoleh atau dihasilkan perusahaan dari ekuitas atau modal yang dimiliki perusahaan. Semakin tinggi nilai return on equity maka semakin tinggi pula laba yang dihasilkan perusahaan dari ekuitas atau modal yang dimilikinya. Berdasarkan grafik di atas, terlihat bahwa return on equity LSIP di tahun 2014 sebesar $0.13 \%$, kemudian di tahun berikutnya menjadi semakin turun. Dan di tahun 2019 mencapai $0.03 \%$. Artinya keuntungan yang dihasilkan LSIP dari ekuitas yang dimiliki dalam 6 tahun mengalami penurunan. Sedangkan pergerakan SIMP pada tahun 2014 return on equity nya sebesar $0,07 \%$ dan menurun terus sampai tahun 2019 dengan angka minus 0.04\%. Sehingga jika LSIP dibandingkan dengan SIMP dari tahun ke tahun, return on equity LSIP lebih baik dari SIMP, artinya LSIP mempunyai keuntungan yang lebih tinggi dibanding SIMP dari ekuitas yang dimiliki.

\section{KESIMPULAN}

Berdasarkan analisis rasio keuangan PT Perusahaan Perkebunan London Sumatera Indonesia Tbk (LSIP) dibandingkan dengan PT. Salim Ivomas Pratama Tbk (SIMP) yang dilakukan dapat diperoleh kesimpulan sebagai berikut :

- Current ratio PT Perusahaan Perkebunan London Sumatera Indonesia Tbk (LSIP) lebih baik dibandingkan dengan PT. Salim Ivomas Pratama Tbk (SIMP).

- Quick ratio PT Perusahaan Perkebunan London Sumatera Indonesia Tbk (LSIP) lebih baik dibandingkan dengan PT. Salim Ivomas Pratama Tbk (SIMP).

- Total debt ratio PT Perusahaan Perkebunan London Sumatera Indonesia Tbk (LSIP) lebih baik dibandingkan dengan PT. Salim Ivomas Pratama Tbk (SIMP).

- Debt equity ratio PT Perusahaan Perkebunan London Sumatera Indonesia Tbk (LSIP) lebih baik dibandingkan dengan PT. Salim Ivomas Pratama Tbk (SIMP).

- Equity Multiplier PT Perusahaan Perkebunan London Sumatera Indonesia Tbk (LSIP) lebih baik dibandingkan dengan PT. Salim Ivomas Pratama Tbk (SIMP).

- Capital structure PT Perusahaan Perkebunan London Sumatera Indonesia Tbk (LSIP) lebih baik dibandingkan dengan PT. Salim Ivomas Pratama Tbk (SIMP).

- Receivable turnover PT Perusahaan Perkebunan London Sumatera Indonesia Tbk (LSIP) lebih baik dibandingkan dengan PT. Salim Ivomas Pratama Tbk (SIMP).

- Day's sale in receivable PT Perusahaan Perkebunan Lond on Sumatera Indonesia Tbk (LSIP) lebih baik dibandingkan dengan PT. Salim Ivomas Pratama Tbk (SIMP). 
- Inventory turnover PT Perusahaan Perkebunan London Sumatera Indonesia Tbk (LSIP) lebih baik dibandingkan dengan PT. Salim Ivomas Pratama Tbk (SIMP).

- Days sales turnover PT Perusahaan Perkebunan London Sumatera Indonesia Tbk (LSIP) lebih baik dibandingkan dengan PT. Salim Ivomas Pratama Tbk (SIMP).

- Total asset turnover PT Perusahaan Perkebunan London Sumatera Indonesia Tbk (LSIP) lebih baik dibandingkan dengan PT. Salim Ivomas Pratama Tbk (SIMP).

- Profit margin PT Perusahaan Perkebunan London Sumatera Indonesia Tbk (LSIP) lebih baik dibandingkan dengan PT. Salim Ivomas Pratama Tbk (SIMP).

- Return on asset PT Perusahaan Perkebunan London Sumatera Indonesia Tbk (LSIP) lebih baik dibandingkan dengan PT. Salim Ivomas Pratama Tbk (SIMP).

- Return on equity PT Perusahaan Perkebunan London Sumatera Indonesia Tbk (LSIP) lebih baik dibandingkan dengan PT. Salim Ivomas Pratama Tbk (SIMP).

Dari 14 analisis rasio laporan keuangan maka kesimpulan secara keseluruhan adalah PT Perusahaan Perkebunan London Sumatera Indonesia Tbk (LSIP) lebih baik dibandingkan dengan PT. Salim Ivomas Pratama Tbk (SIMP)

DAFTAR PUSTAKA

1. Dr. Bambang Santoso Marsoem, MA., Analisis Ratio Keuangan. Catatan Ajar bidang studi Corporate Finance Management S2 universitas Mercu Buana

2. Prof.Dr. Suryana, M.Si., 2010. Metodologi Penelitian Model Prakatis Penelitian Kuantitatif dan Kualitatif. Buku Ajar Kuliah Universitas Pendidikan Indonesia.

3. https://www.kompasiana.com/ria_buchari/5730977c5493731b0a0a4774/pentingnyaind ustrialisasi-di-sektor-perkebunan

4. https://www.jurnal.id/id/blog/5-langkah-melakukan-analisis-rasio-keuangan/

5. https://www.idnfinancials.com/ 